\title{
STRATEGI DAN IMPLEMENTASI DIGITAL MARKETING SELAMA PANDEMI COVID-19
}

\author{
Margarita Ekadjaja $^{1}$ dan Halim Putera Siswanto
}

\author{
${ }^{1}$ Jurusan Manajemen, Universitas Tarumanagara, Jakarta \\ Email: margaritae@fe.untar.ac.id \\ ${ }^{2}$ Jurusan Manajemen, Universitas Tarumanagara, Jakarta \\ Email: halims@fe.untar.ac.id
}

\begin{abstract}
The Covid-19 Pandemic has been greatly affecting micro, small, and medium businesses, especially since the government issued the regulation on large-scale social distancing in order to reduce the spread of Corona virus. This community-engagement service activity aimed to socialize the digital marketing to market the products related to the Industrial Revolution 4.0 era and the existence of Covid-19 Pandemic. Limun Sari Buah is a type of medium-scale business established in 1970 producing lemonade drinks which are sold per crate consisting of $600 \mathrm{ml}$ bottles. Currently, the sale of Limun Sari Buah is decreased due to the people's activities reduction due to the pandemic and the lack of available flavor variants. The team of Community-Engagement Services attempts to provide a solution to Limun Sari Buah in the field of marketing according to the Industrial Revolution 4.0 era and diversifying the lemonade-drink product variants. The efforts done by the team of UNTAR Community-Engagement Services was by providing a training on marketing 4.0 entitled: The Strategy and Implementation of Digital Marketing in 4.0 Era through a webinar. The target of this community-engagement service activity for the business-owner and marketers is being able to market the products digitally by utilizing the internet media. After participating in the Marketing 4.0 Training, partners can use the internet media to market their products through Instagram. According to the result of a survey among 105 respondents in the age between 20-50 years old, the team of community-engagement services provide a solution to Limun Sari Buah to add new variants of the lemonade-drink product such as ginger-extract and milk-coffee. The output of this community-engagement service activity is disseminated in a National Seminar and Opini Untar.
\end{abstract}

Keywords: Industry Revolution 4.0, conventional marketing, digital marketing, internet media

\begin{abstract}
ABSTRAK
Pandemi Covid-19 berdampak besar pada usaha bisnis berskala mikro, kecil, dan menengah terutama sejak pemerintah mengeluarkan peraturan mengenai Pembatasan Sosial Berskala Besar dalam rangka mengurangi penyebaran virus Corona. Tujuan kegiatan abdimas ini adalah mensosialisasikan digital marketing untuk memasarkan produk sehubungan dengan era Revolusi Industri 4.0 dan terjadinya wabah pandemi Covid-19. Limun Sari Buah merupakan usaha bisnis berskala menengah, didirikan tahun 1970 dengan produk yang dihasilkan berupa limun dan dijual secara konvensional per krat dengan ukuran 600 ml per botol. Saat ini penjualan Limun Sari Buah berkurang karena berkurangnya aktivitas masyarakat keluar rumah akibat pandemi dan kurangnya varian rasa yang tersedia. Tim Abdimas berupaya memberikan solusi kepada Limun Sari Buah di bidang pemasaran sesuai era Revolusi Industri 4.0 dan di bidang diversifikasi varian produk minuman limun. Upaya yang dilakukan Tim Abdimas UNTAR adalah memberikan pelatihan pemasaran 4.0 dengan topik Strategi dan Implementasi Digital Marketing di Era 4.0 melalui webinar. Target kegiatan abdimas adalah pemilik dan tenaga pemasar mampu memasarkan produknya secara digital dengan pemanfaatan media internet. Setelah mengikuti pelatihan pemasaran 4.0, mitra dapat memanfaatkan media internet untuk memasarkan produknya melalui instagram. Berdasarkan hasil survei varian rasa tertinggi dari 105 responden yang berusia 20-50 tahun, Tim Abdimas memberikan solusi kepada Limun Sari Buah untuk menambah varian produk minuman limun, seperti sari jahe dan kopi susu. Luaran kegiatan abdimas ini dipublikasikan dalam Seminar Nasional dan Opini Untar.
\end{abstract}

Kata Kunci: Revolusi Industri 4.0, pemasaran konvensional, digital marketing, media internet

\section{PENDAHULUAN}

Pandemi Covid-19 yang mulai masuk ke Indonesia pada awal tahun 2020 menyebabkan melambatnya berbagai kegiatan bisnis. Pandemi Covid-19 juga berdampak besar bagi usaha bisnis yang berskala mikro, kecil, dan menengah, terutama UMKM yang menjalankan bisnisnya secara konvensional. Ekonomi masyarakat menurun, terutama sejak adanya kebijakan pemerintah dengan 
mengeluarkan peraturan mengenai Pembatasan Sosial Berskala Besar (PSBB) dalam rangka mengurangi penyebaran virus Covid-19.

Selama PSBB, terjadi pengaturan pembatasan jumlah karyawan yang bekerja, pengurangan jam operasional saat bekerja di luar, sehingga masyarakat lebih banyak melakukan pekerjaannya dari rumah. Hal ini menyebabkan banyak UMKM mengalami kerugian besar, dan bahkan juga banyak UMKM harus mengalami gulung tikar. Penyebabnya adalah minimnya pengetahuan UMKM mengenai teknologi sehingga mereka sulit untuk beradaptasi. Menurut Jatmika (2016), UMKM merupakan kesempatan bisnis yang produktif, yang berkontribusi dalam pertumbuhan ekonomi, namun masih minimnya pengetahuan berbisnis dan kesulitan dalam permodalan sehingga mereka sulit untuk mengembangkan usahanya.

Menurut Rosita (2020), Pandemi Covid-19 menyebabkan banyak sektor usaha terpuruk terutama UMKM. Saat ini,jumlah masyarakat yang terkena virus Corona semakin meningkat, menyebabkan risiko bisnis menjadi meningkat. Meningkatnya risiko bisnis juga dirasakan oleh UMKM Limun Sari Buah yang bergerak dalam produksi minuman limun.

UMKM Limun Sari Buah merupakan perusahaan perorangan yang didirikan pada tahun 1970, yang mana pada awalnya bernama Harapan Baru. Kemudian pada tahun 1986, berubah nama menjadi Sari Baru, dan pada tahun 2015 berubah menjadi Limun Sari Buah. Produksi yang dihasilkan adalah berupa limun dengan rasa orange-cruiser, sarsaparilla, dan cream-soda. Kemudian seiring berubahnya selera pelanggan, UMKM Limun Sari Buah mengeluarkan rasa pisang ambon dan nanas, kedua rasa tersebut menjadi favorit bagi para pelanggannya. Penjualan limun tersebut dilakukan per krat, 1 krat berisi 24 botol dengan ukuran $600 \mathrm{ml}$.

Pelanggan lamanya adalah depot minuman, yang penjualannya dilakukan secara konvensional melalui metode door-to-door atau salesman, dengan jumlah karyawan tetap sebanyak 5 orang dan 10 orang berupa buruh harian. Wilayah pemasarannya masih terbatas di daerah sekitar Tangerang, Jakarta, dan Jawa Barat.

Lokasi pabrik Limun Sari Buah adalah di daerah Tangerang. Gambar 1 menunjukkan tempat produksi, bahan baku, dan barang jadi dari Limun Sari Buah yang ditempatkan di dalam lokasi yang sama. Adapun bahan baku yang diperlukan adalah air gula, essence, pewarna, sari buah, dan mesin $\mathrm{CO}_{2}$.

Krisis bisnis menyebabkan penjualan limun menurun karena berkurangnya konsumen seiring dengan maraknya wabah Covid-19, pemutusan hubungan kerja, dan pembatasan sosial. Penurunan penjualan limun sulit dihindari karena cara penjualannya yang masih tergolong konvensional. Pemilik UMKM Limun Sari Buah tergolong generasi baby-boomers (kelahiran 1945-1964) dan belum memiliki pengetahuan mengenai pemasaran online. Menurut (Adiawaty, 2019), perbedaan generasi akan mempengaruhi perilaku bisnis, generasi baby-boomers cenderung menyukai cara berjualan melalui tatap muka dengan para pembeli.

Gambar 2 menunjukkan grafik penjualan minuman per bulan. Berdasarkan grafik tersebut, terlihat adanya penurunan yang cukup drastis pada saat pemerintah mulai memberlakukan PSBB pada awal April 2020, dan jumlah penjualan yang cenderung terus menurun pada bulan-bulan berikutnya. Pada Gambar 2, belum terlihat adanya perbaikan menuju ke tingkat penjualan sebelum masa pandemi. 


\section{Gambar 1}

Pabrik Limun Sari Buah
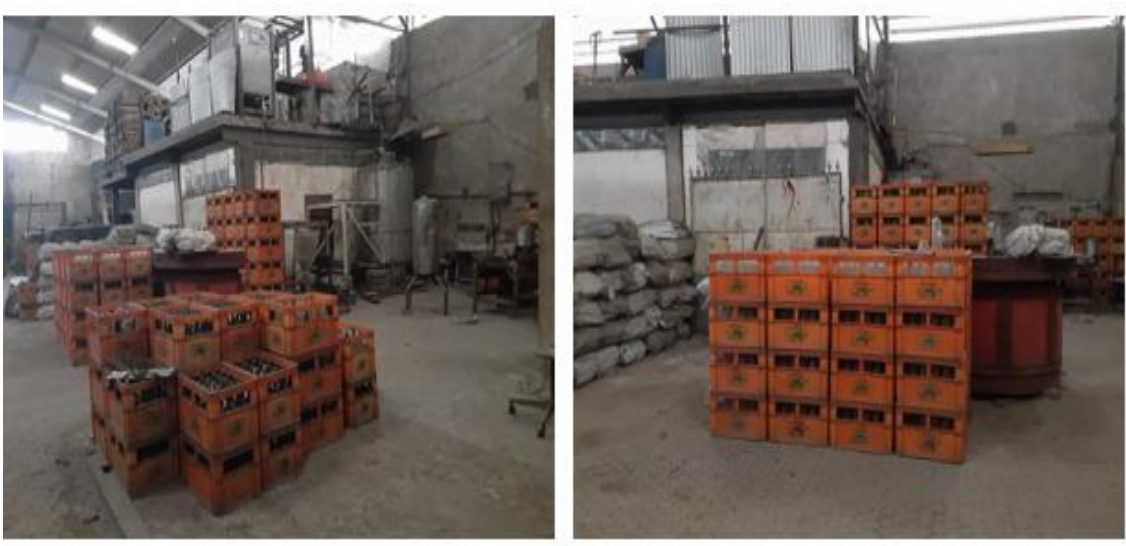

\section{Gambar 2}

Grafik Penjualan Limun Sari Buah

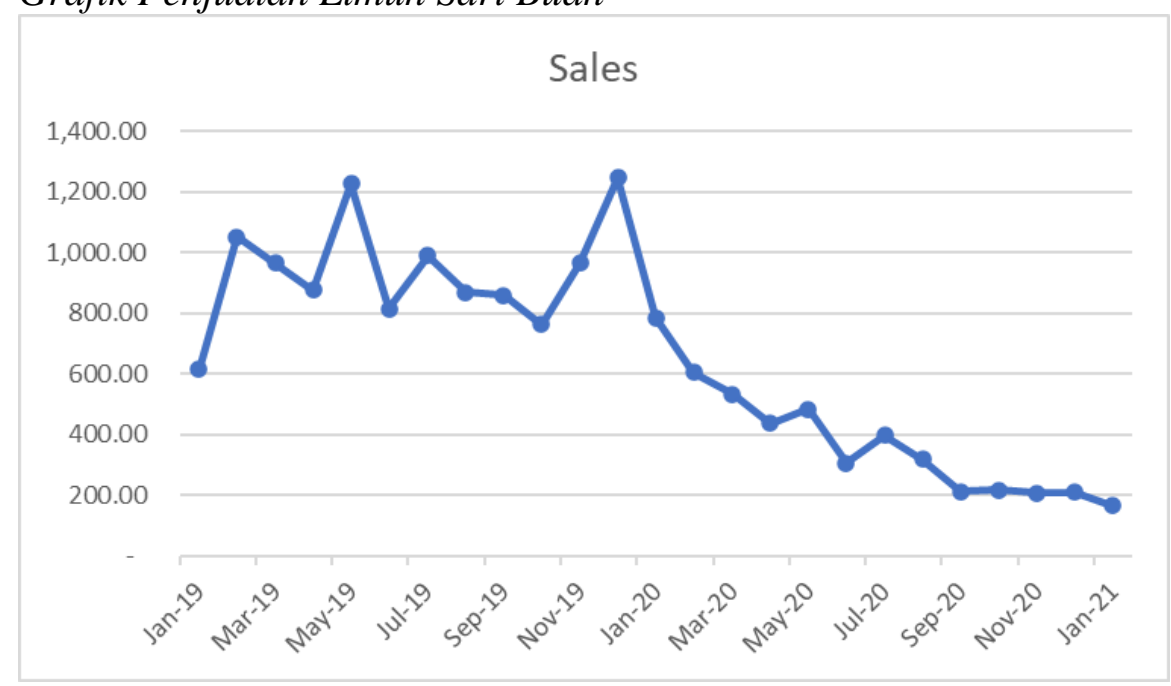

\section{Gambar 3}

Konsep Pemasaran 4.0 (Kotler et al, 2019)

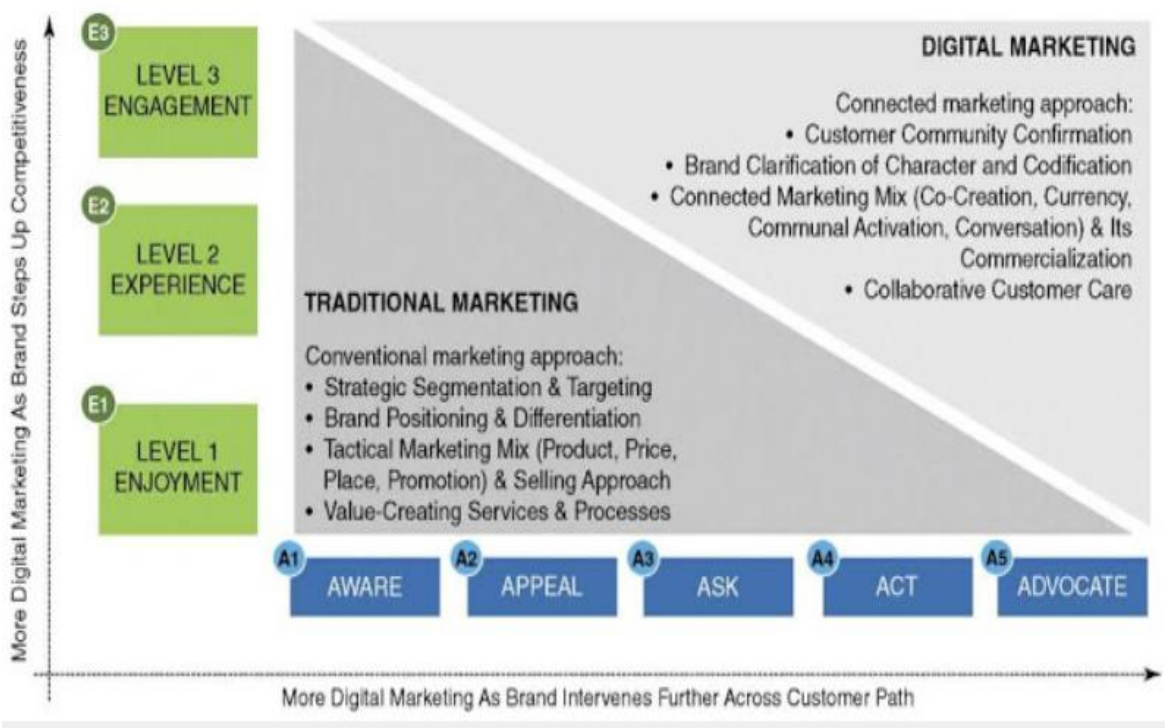


Menurut (Rohimah, 2019), pada era Revolusi Industri 4.0, banyak pemilik usaha yang tidak dapat melanjutkan usahanya karena mereka masih menawarkan produknya secara konvensional. Pada era 4.0 ini, kegiatan pemasaran suatu produk dapat dilakukan melalui pemanfaatan media internet. Setiap orang yang mempunyai kegiatan usaha dapat melakukan kegiatan pemasaran atas produknya dengan mudah, cepat, dan memilki jangkauan pemasaran yang luas, karena tidak lagi dibatasi oleh ruang dan waktu.

Tim Abdimas Universitas Tarumanagara memberikan pelatihan mengenai digital marketing kepada UMKM Limun Sari Buah untuk memperluas pangsa pasarnya melalui pemasaran digital. Pemasaran digital merupakan kegiatan pemasaran melalui media internet, internet telah menjadi aktivitas manusia di era 4.0. Menurut Purwana, et. al (2017), digital marketing merupakan usaha untuk memperkenalkan merek kepada masyarakat dengan menggunakan media digital.

Berdasarkan Gambar 3, terlihat bahwa konsep pemasaran 4.0 adalah mengubah pemasaran tradisional menuju ke pemasaran digital dengan keuntungan dalam mengatasi daya saing melalui merek yang lebih dikenal masyarakat, sehingga secara langsung akan meningkatkan jumlah konsumen.

\section{METODE PELAKSANAAN PKM}

Pelaksanaan PKM ini dibagi menjadi dua tahapan, yaitu tahapan solusi di bidang pemasaran dan tahapan solusi di bidang diversifikasi varian produk.

\section{Tahapan Solusi di Bidang Pemasaran}

Pada tahapan ini, upaya yang dilakukan oleh Tim Abdimas UNTAR adalah memberikan pelatihan dengan topik: Strategi dan Implementasi Digital Marketing di Era 4.0 melalui webinar. Webinar tersebut dikemas dalam bentuk video yang interaktif sehingga mudah untuk dipahami, karena webinar ini merupakan langkah awal bagi Tim Abdimas memperkenalkan manfaat dan cara memasarkan produk secara digital. Di dalam webinar ini, juga dilakukan diskusi dan sesi sharing dari mahasiswi Fakultas Ekonomi dan Bisnis, Universitas Tarumanagara, Program Studi S-1 Akuntansi, yang telah berhasil menjual produknya dengan menggunakan media internet. Target peserta webinar adalah pemilik dan tenaga pemasar yang tidak hanya memasarkan produknya secara konvensional, melainkan juga dapat memasarkan produknya secara digital sesuai dengan perkembangan era 4.0 dan Pandemi Covid-19.

\section{Tahapan Solusi di Bidang Diversifikasi Varian Produk}

Solusi di bidang diversifikasi varian produk minuman limun juga perlu dilakukan dalam upaya untuk memenuhi selera konsumen yang disesuaikan dengan situasi saat terjadinya Pandemi Covid19. Dalam tahapan ini, Tim Abdimas melakukan survei terhadap beberapa responden selaku konsumen, mengenai jenis minuman yang menjadi pertimbangan untuk dibeli pada saat terjadinya Pandemi Covid-19.

Metode pelaksanaan kegiatan Pengabdian kepada Masyarakat UMKM Limun Sari Buah dapat dilihat pada Gambar 4. Berdasarkan Gambar 4, tahapan pelaksanaan kegiatan Abdimas diawali dengan diskusi, yang mana Tim Abdimas melakukan investigasi mengenai tujuan dari khalayak mitra untuk meningkatkan penjualannya, yang mana pada tahapan ini Tim Abdimas dapat merumuskan permasalahan mitra. Pada tahap selanjutnya, Tim Abdimas mengajukan usulan mengenai solusi atas permasalahan kepada mitra. Adapun tahapan solusi permasalahan yang disetujui oleh mitra dikategorikan menjadi dua bagian, yaitu tahapan solusi di bidang pemasaran 
dan tahapan solusi di bidang diversifikasi produk. Tahap akhir dari kegiatan abdimas ini adalah pelaksanaan evaluasi untuk mengukur keberhasilan dari kegiatan Abdimas yang telah dilakukan.

\section{Partisipasi Mitra}

Mitra di dalam kegiatan Abdimas ini adalah UMKM Limun Sari Buah, yang merupakan sebuah produsen minuman limun. Kegiatan Abdimas UNTAR mendapat dukungan dari mitra untuk pelaksanaan webinar mengenai strategi dan implementasi digital marketing di era 4.0. Besar harapan mitra, setelah kegiatan webinar ini UMKM Limun Sari Buah dapat menerapkan pemasaran digital dalam rangka memperoleh pangsa pasar yang baru, sehingga penjualan produknya dapat meningkat.

\section{Gambar 4}

Tahapan Pelaksanaan Kegiatan Abdimas

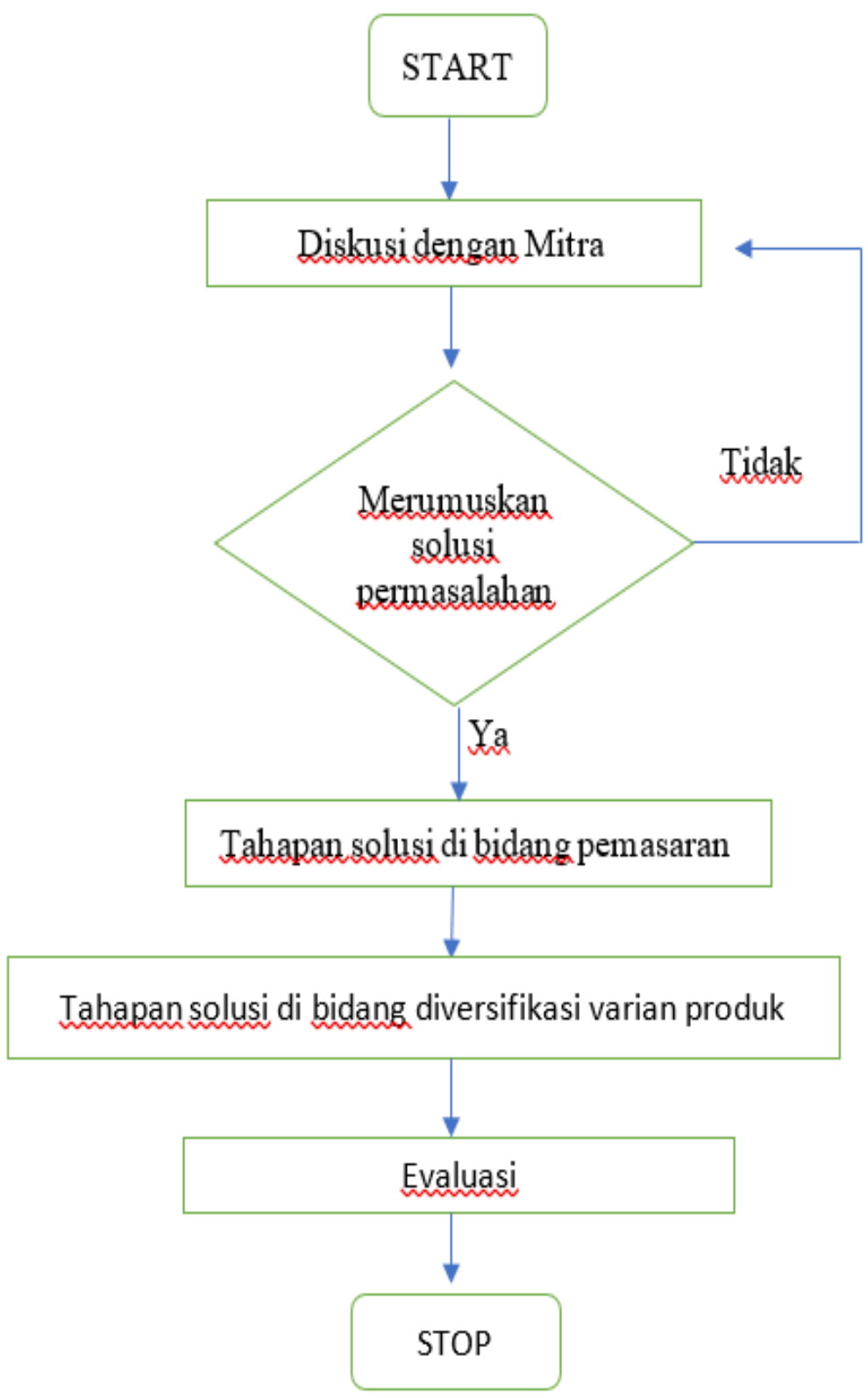




\section{HASIL DAN PEMBAHASAN}

Tim Abdimas UNTAR berupaya membantu UMKM Limun Sari Buah untuk memperluas pangsa pasar dalam rangka penjualan produk Limun Sari Buah, dengan memberikan solusi kepada UMKM Limun Sari Buah untuk berpikir dan bertindak secara inovatif dalam melakukan kegiatan pemasaran yang disesuaikan dengan era 4.0 dan wabah Pandemi Covid-19 dalam bentuk pelatihan. Dalam hal pemasaran produk secara digital, Tim Abdimas mengadopsi kegiatan Pengabdian kepada Masyarakat yang dilakukan oleh Lesmana, et al.(2018) yang menggunakan media internet di dalam memasarkan kerajinan anyaman bambu di wilayah Jember. Sosialisasi mengenai Pemasaran 4.0 dilakukan melalui webinar, pesertanya adalah pemilik dan tenaga pemasar UMKM Limun Sari Buah.

Materi webinar dibuat dalam bentuk video yang bersifat interaktif, yang disertai dengan beberapa contoh UMKM yang sukses memasarkan produknya secara digital serta mengadopsi hasil penelitian Erdisna, et al. (2020) mengenai literasi informasi dan media. Gambaran umum materi yang diberikan meliputi: Materi pertama membahas gambaran secara umum mengenai pemasaran, seperti pemahaman mengenai kegiatan pemasaran dan komunikasi pemasaran. Materi kedua membahas mengenai strategi pemasaran di dalam menyusun rencana, melakukan implementasi, dan mengukur kinerja pemasaran. Materi ketiga membahas mengenai pengembangan strategi bisnis melalui digital marketing, seperti memperkenalkan internet marketing di era 4.0 ini.

Menurut Suhartono \& Richard (2018), media sosial merupakan salah satu strategi komunikasi pemasaran di lingkungan sebuah Perguruan Tinggi di Jakarta Barat. Tim abdimas juga memberikan simulasi pemasaran produk secara digital dengan menggunakan media sosial yang ada, yang disertai dengan pemahaman karakteristik dari setiap platform media sosial tersebut. Pengukuran mengenai keberhasilan webinar adalah kemampuan dari para peserta untuk memasarkan produknya secara online dengan menggunakan media sosial internet yang ada, dalam hal ini Tim Abdimas memperkenalkan media sosial yang bersifat ekspresif dan tidak berbayar, seperti Instagram dan Facebook. Peserta pada umumnya telah memiliki media sosial seperti Facebook, namun media tersebut hanya dipakai dalam hal pertemanan atau urusan pribadi saja.

Pelaksanaan Pelatihan terlihat pada Gambar 5, webinar dilaksanakan hari Sabtu, 27 Maret 2021 dari pukul 15.30-18.00 melalui aplikasi Zoom Meeting. Simulasi pemanfaatan media sosial yang dipilih oleh Tim Abdimas adalah Instagram sebagai sarana pemasaran yang tepat untuk mitra

Pemilihan media sosial instagram sebagai sarana pemasaran paling tepat bagi mitra dikarenakan peserta pelatihan sebelumnya sudah mempunyai akun facebook yang dapat menghubungkan dengan akun instagram. Simulasi pembuatan akun instagram dilakukan menggunakan gawai yang memudahkan untuk pengambilan foto produk mitra. Tahap awal yang adalah membuat profil mitra dan dilanjutkan dengan cara share foto produk Limun Saribuah ke dalam instagram. Hasil dari pelatihan ini mitra dapat membuat iklan di instagram seperti yang terlihat pada Gambar 6.

Dalam hal kurangnya varian rasa, dengan mengacu pada (Khairani \& Pratiwi, 2018), yang memberikan pelatihan diversifikasi produk dan promosi kepada UMKM kerajinan souvenir khas Palembang dengan tujuan untuk meningkatkan omset penjualan dan memperluas pangsa pasar, Tim Abdimas memberikan solusi kepada UMKM Limun Sari Buah untuk menambah varian (diversifikasi) produk minuman limun, seperti sari jahe, kopi susu, dan teh susu. Dukungan yang dilakukan Tim Abdimas dalam hal ini adalah menyebarkan kuesioner menggunakan google form kepada masyarakat yang tinggal di daerah Tangerang dan Jakarta untuk kelompok usia 20-30 
tahun, 31 tahun-40 tahun, dan kelompok usia 41- 50 tahun, mengenai varian produk minuman yang disukai.

Berdasarkan hasil survei, Tim Abdimas mengusulkan kepada mitra untuk menambah varian produk minuman limun, berupa sari jahe dan kopi susu. Limun rasa jahe hampir disukai oleh seluruh responden di kelompok usia 20-50 tahun, dengan mengingat pada saat terjadinya Pandemi Covid 19, banyak konsumen bersedia membeli jahe dan produk jahe untuk meningkatkan imunitas mereka. Di sisi lain, limun rasa kopi susu sangat diminati oleh generasi $\mathrm{Z}$ dan generasi Milenial yang masuk ke dalam kelompok usia 20-40 tahun.

\section{Gambar 5}

\section{Pelaksanaan Webinar Pemasaran 4.0}

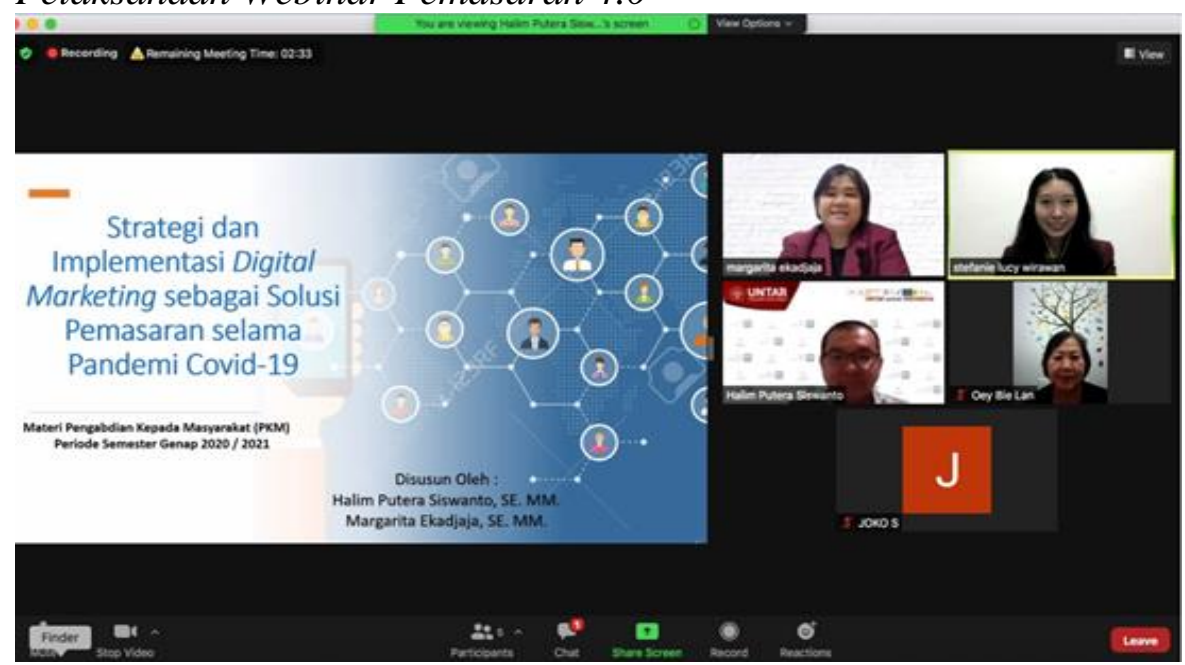

\section{Gambar 6}

\section{Hasil Pelatihan}

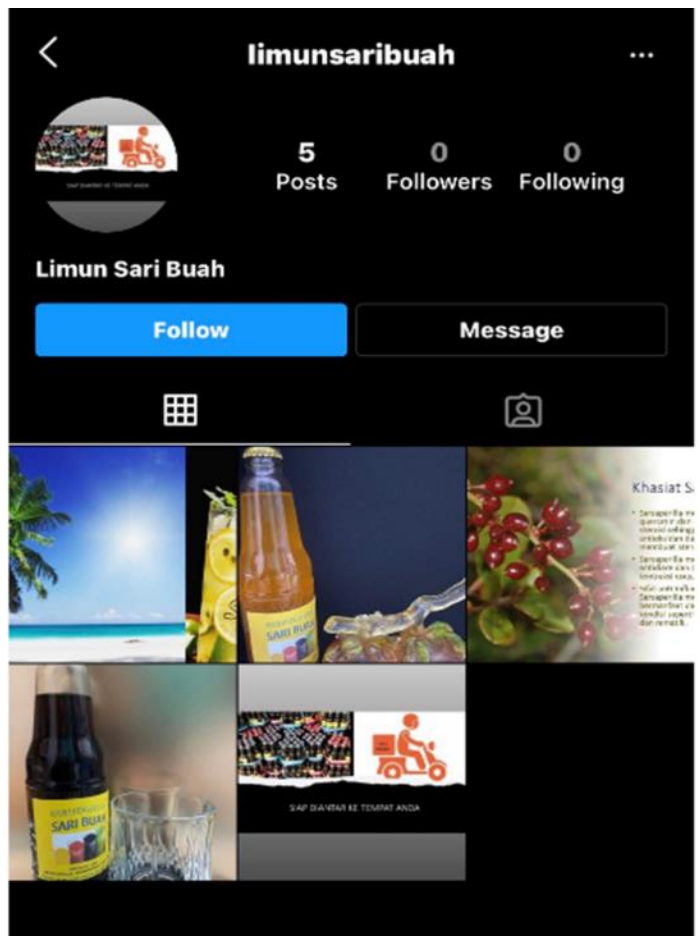




\section{Gambar 7}

\section{Hasil Survey Varian Limun}

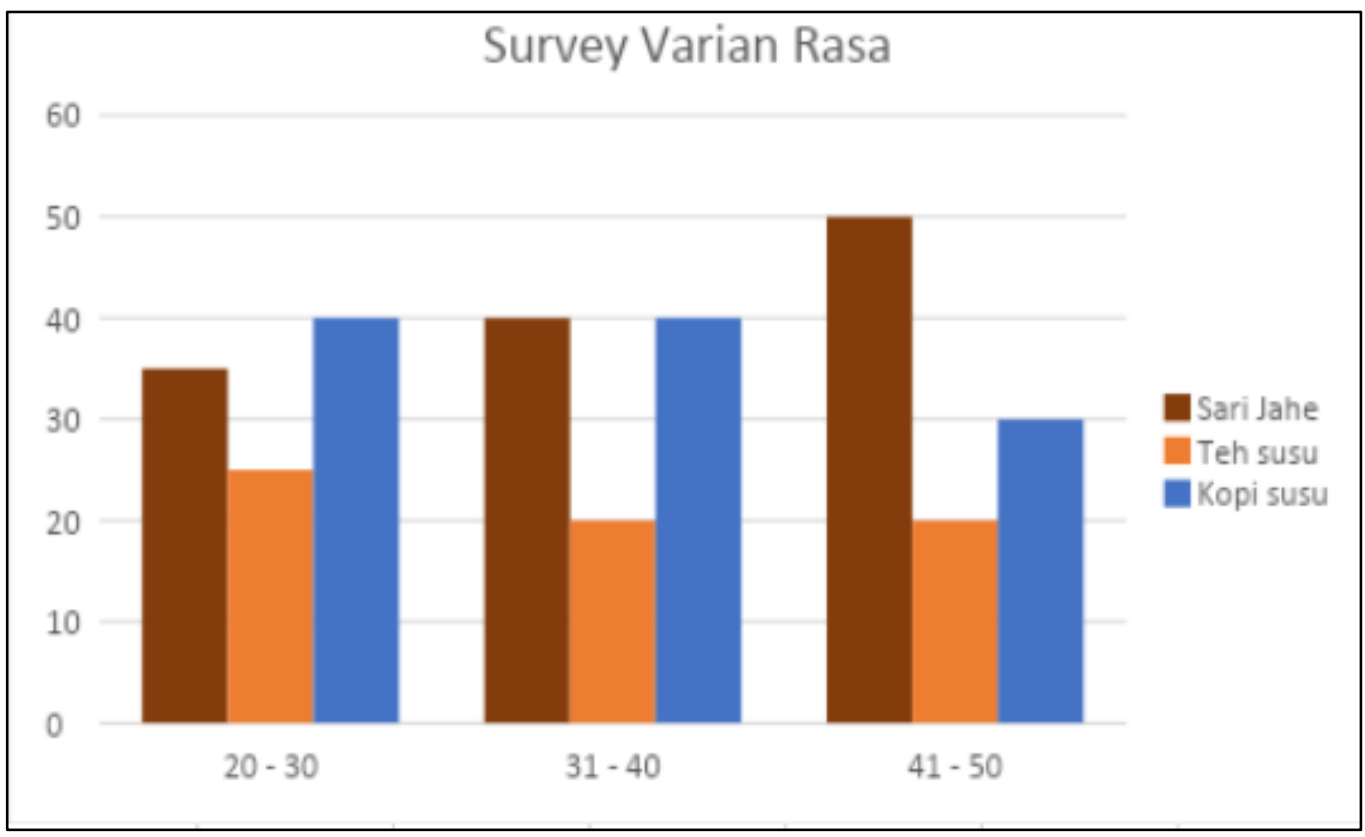

Hasil kuesioner yang disebar oleh Tim Abdimas melalui Google Form dapat dilihat pada Gambar 7. Penyebaran kuesioner dibagi menjadi tiga kelompok usia, yakni kelompok usia 20-30 tahun, kelompok usia 31-40 tahun, dan kelompok usia 41-50 tahun. Jumlah kuesioner yang berhasil terkumpul berasal dari 105 responden. Berdasarkan hasil kuesioner, diketahui bahwa kelompok usia 20-30 tahun cenderung menyukai varian minuman kopi susu, kelompok usia 31-40 tahun lebih menyukai varian minuman sari jahe dan kopi susu, sedangkan kelompok usia 41-50 tahun lebih menyukai varian minuman sari jahe.

\section{KESIMPULAN DAN SARAN}

Pandemi Covid-19 memberikan dampak terbesar pada penurunan penjualan UMKM Limun Sari Buah. Penurunan penjualan limun sulit dihindari karena adanya cara penjualan yang masih konvensional dan kurangnya variasi rasa. Tim Abdimas UNTAR berupaya untuk membantu meningkatkan penjualan UMKM Limun Sari Buah dengan memberikan solusi permasalahan di bidang pemasaran terkait dengan pemanfaatan media sosial dalam memasarkan produk dan di bidang diversifikasi varian produk.

Dalam hal solusi permasalahan di bidang pemasaran, Tim Abdimas telah menyelenggarakan webinar mengenai pemasaran sesuai dengan era Revolusi Industri 4.0 dengan topik: "Strategi dan Implementasi Digital Marketing sebagai Solusi Pemasaran selama Pandemi Covid-19”. Peserta webinar adalah pemilik dan tenaga pemasar dari UMKM Limun Sari Buah. Setelah pelaksanaan webinar, mitra dapat memasarkan produk limun melalui media sosial Instagram.

Dalam hal solusi permasalahan di bidang diversifikasi varian produk, Tim Abdimas melakukan survei melalui penyebaran kuesioner dengan menggunakan Google Form kepada responden yang berusia 20-50 tahun. Total kuesioner yang berhasil terkumpul berasal dari 105 responden dan terbagi menjadi tiga kelompok usia (kelompok usia 20-30 tahun, 31-40 tahun, dan 41-50 tahun). Berdasarkan hasil survei, Tim Abdimas mengusulkan kepada mitra untuk menambah varian produk minuman limun berupa sari jahe dan kopi susu mengingat minuman tersebut banyak dicari konsumen untuk meningkatkan daya tahan tubuh mereka saat Pandemi Covid 19 ini. 
Sebagai saran, sebaiknya perlu dilakukan pelatihan lebih lanjut kepada mitra dalam hal pembuatan iklan secara digital melalui Tik-Tok dan Youtube, sehingga konsumen menjadi tertarik atas produk yang ditawarkan di media sosial, seperti Instagram dan Facebook, di dalam upaya memasarkan produk minuman Limun Sari Buah.

\section{Ucapan Terima Kasih (Acknowledgement)}

Tim Abdimas mengucapkan terima kasih kepada LPPM-UNTAR yang telah mendanai seluruh kegiatan abdimas ini dengan Surat Perjanjian Kontrak Nomor : 177-Int-KLPPM/UNTAR/II/2021, dan juga kepada FEB UNTAR yang telah membantu dalam hal administrasi kegiatan abdimas ini. Tak lupa, Tim Abdimas juga mengucapkan terima kasih kepada Bapak Harry selaku pemilik UMKM Limun Sari Buah yang telah memberikan izin untuk pelaksanaan kegiatan abdimas ini, dan kepada Stefanie Lucy Wirawan selaku mahasiswi Program Studi S-1 Akuntansi FEB UNTAR yang telah ikut serta membantu di dalam pelaksanaan kegiatan webinar.

\section{REFERENSI}

Adiawaty, S. (2019). Tantangan perusahaan mengelola perbedaan generasi karyawan. Jurnal Manajemen Bisnis, 22(3), 376-382.

Erdisna, Ganefri, Ridwan, Efendi, R., \& Masril, M. (2020). Effectiveness of entrepreneur digital learning model in the industrial revolution 4.0. International Journal of Scientific and Technology Research, 9 (3), 5611-5616.

Jatmika, R. T. D. (2016). Masalah yang dihadapi usaha kecil menengah di indonesia. Jurnal Studi Ekonomi Syariah, 2(6).

Khairani, S., \& Pratiwi, R. (2018). Peningkatan omset penjualan melalui diversifikasi produk dan strategi promosi pada umkm kerajinan souvenir khas palembang. Caradde: Jurnal Pengabdian Kepada Masyarakat, 1(1), 36-43.https://doi.org/10.31960/caradde.v1i1.18

Kotler, P., Kartajaya, H., \& Hooi, D. H. (2019). Marketing 4.0: moving from traditional to digital in asian competitor. World Scientific Publishing Co. Pte. Ltd. https://doi.org/10.1142/9789813275478_0004

Lesmana, I. P. D., Widiawan, B., \& Hartadi3, D. R. (2018). Pengembangan pemasaran online kerajinan anyaman bambu antirogo jember melalui media internet. Jurnal Bakti Masyarakat Indonesia, 1(1),17-24.

Prastyaningtyas, E. W., \& Arifin, Z. (2019). Pentingnya pendidikan kewirausahaan pada mahasiswa dengan memanfaatkan teknologi digital sebagai upaya menghadapi revolusi 4.0. Proceedings of the ICECRS, 2(1), 281-286. https://doi.org/10.21070/picecrs.v2i1.2382

Purwana, D., Rahmi, R., \& Aditya, S. (2017). Pemanfaatan digital marketing bagi usaha mikro, kecil, dan menengah (UMKM) di kelurahan malaka sari, duren sawit. Jurnal Pemberdayaan Masyarakat Madani (JPMM), 1(1),1-17. https://doi.org/10.21009/jpmm.001.1.01

Rohimah, A. (2019). Era digitalisasi media pemasaran online dalam gugurnya pasar ritel konvensional. KANAL: Jurnal Ilmu Komunikasi, 6(2), 91-100. https://doi.org/10.21070/kanal.v6i2.1931

Rosita, R. (2020). Pengaruh pandemi covid-19 terhadap umkm di indonesia. Jurnal Lentera Bisnis, 9(2), 109-120.https://doi.org/10.34127/jrlab.v9i2.380

Suhartono Chandra \& Richard Andrew.(2018). Peran media sosial dalam strategi komunikasi pemasaran di sebuah perguruan tinggi swasta di jakarta barat. 2(2), 535-542 